\title{
МЕТОДИ ДІАГНОСТИКИ ПОРУШЕНЬ СЛУХУ У ДІТЕЙ
}

\author{
Г. М. Кожушко, О. А. Прокопович \\ Криворізький державний медичний коледж \\ Криворізька медична дитяча лікарня № 1 \\ ДВНЗ «Тернопільський державний медичний університет \\ імені І. Я. Горбачевського МОЗ України"
}

У статті детально розкрито методи та види діагностики порушень слуху в дітей.

\section{METHODS OF DIAGNOSTICS OF HEARING DISORDERS IN CHILDREN}

\author{
G. M. Kozhushko, O. A. Prokopovych \\ Kryvyi Rih Medical College \\ Kryvyi Rih Medical Children's Hospital No. 1 \\ I. Horbachevsky Ternopil State Medical University
}

The article details the methods and types of diagnostics of hearing impairment in children.

Вступ. Нормальне функціонування органа слуху має одне з вирішальних значень для загального розвитку людини. Це визначається тим, що завдяки слуховому аналізатору людина отримує інформацію про навколишній світ. На жаль, останнім часом збільшилась кількість дітей з вродженими вадами слуху.

Відповідно до наукових досліджень, більшість дітей, які не чують, має вроджені вади слуху. Але в Україні у віці до трьох-чотирьох років виявляють тільки частину таких дітей. Часто батьки помічають у малюка якесь відхилення у реакціях, поведінці, однак списують особливості характеру дитини, сподіваються, що вона «переросте» цю своєрідність і далі буде розвиватись нормально. Реально такий розвиток подій практично неможливий - проблема зниження слуху призводить до затримки мовного та інтелектуального розвитку, навичок спілкування, подолати які у шкільному віці надзвичайно важко. Наш мозок, починаючи від народження, весь час навчається, реагує на подразники оточуючого світу, засвоює мовні, зорові, слухові та інші сенсорні образи, потім користується ними для дій в оточуючому світі [6].

У зв'язку з цим, важливого значення набуває раннє виявлення порушень слуху за допомогою сучасних діагностичних методів та правильна оцінка потен-

(с) Г. М. Кожушко, О. А. Прокопович, 2018 ційних можливостей слухової системи таких дітей. Діагностику повинен виконувати лікар-отоларинголог-аудіолог, оскільки від діагнозу і правильної оцінки стану слухової функції залежить успіх усіх наступних заходів щодо реабілітації вад слуху, а потім іуспішного процесу навчання.

Основна частина. Обстеження пацієнта із захворюванням вуха починають з бесіди з ним, під час якої з'ясовують скарги хворого, історію захворювання та інших захворювань (анамнез), потім виконують об'єктивне обстеження вуха, проводять функціональні дослідження слуху та вестибулярного апарату. Оскільки більшість вушних хвороб пов'язана із захворюваннями носа та глотки, їх обстеження повинно передувати обстеженню вуха.

Скарги, які змусили хворого звернутись за допомогою, можуть включати:

а) біль увухах, що має різний характер та інтенсивність;

б) виділення з вуха - оторея;

в) зниження слуху або глухоту;

г) шум у вухах (свист, гул, пульсація);

д) запаморочення та порушення рівноваги тіла,

е) нудоту, блювання тощо.

Не менш важливо з'ясувати загальне самопочуття хворого, наявність головного болю, підвищення температури тіла, ознобу тощо [5]. 
При зборі анамнезу цього захворювання з'ясовують причини і перші прояви хвороби, її перебіг, чи проводилось у минулому лікування і яке? Потім переходять до збору анамнезу життя (загальний стан здоров'я, інші перенесені захворювання, умови праці та побуту тощо).

Об'єктивне обстеження вуха включає огляд зовнішнього вуха, пальпацію вушної раковини, козелка, соскоподібного відростка, проведення отоскопії, а також дослідження слухової та вестибулярної функцій (акуметрія, аудіометрія, вестибулометрія тощо).

Додаткові методи обстеження вуха включають лабораторні аналізи крові, сечі, спинномозкової рідини та виділень з вуха (посів на чутливість до антибіотиків); рентгенологічні методи обстеження (рентгенографія, комп'ютерна томографія) та ядерномагнітно-резонансне дослідження тощо.

П. А. Затолока поділяє всі методи дослідження слуху на 2 групи:

1. Суб'єктивні (психоакустичні): дослідження слуху мовою; дослідження слуху за допомогою камертонів; суб'єктивна аудіометрія.

2. Об'єктивні: об'єктивна (комп'ютерна) аудіометрія; акустична рефлексометрія; тимпанометрія; отоакустична емісія; безумовні рефлекторні реакції; умовні реакції на звук [1].

Існують різноманітні методи визначення слухової функції, більшість з яких ґрунтується на суб'єктивних даних обстежуваного про сприйняття почутих звуків. До них належать визначення рівня сприйняття шепітної та розмовної мови, камертональні досліди (акуметрія), тональна, мовна, надпорогова та імпедансна аудіометрія. Протягом останніх років почали застосовувати методи об'єктивного дослідження слухової функції. Ці методи включають визначення коротколатентних слухових викликаних потенціалів, імпедансну аудіометрію, отоакустичну емісію та деякі інші.

Дослідження проводять у тихому приміщенні достатньої величини (хоча 66 м в одному напрямі). Кожне вухо досліджують окремо, спочатку шепітною мовою, потім розмовною. Хворий стаєу найтихіший куток приміщення та повертається вухом до лікаря, щоб не бачити його обличчя і не зчитувати слів за рухами губ. При цьому пацієнт закриває друге вухо вказівним пальцем, яким міцно перекриває вхіду зовнішній слуховий прохід. При проведенні експертизи слуховий прохід закриває не обстежуваний, а медична сестра, щоб отримати більш об'єктивні дані. Лікар відходить на 6 м від хворого і пошепки говорить слова, які пацієнт повинен відразу ж повторити. Сила шепоту має бути завжди однаковою.
Щоб цього досягти, потрібно зробити спокійний видих і вимовляти слова, користуючись лише повітрям, яке залишилось у легенях. На практиці використовують двозначні числа від 21 до 99 (за винятком круглих чисел), підбираючи спочатку числа з глухими приголосними, в яких переважають низькочастотні звуки (наприклад, «тридцять два», «двадцять п'ять»); а потім слова з шиплячими, в яких переважають високочастотні звуки (наприклад, «сімдесят шість», «сорок сім»). Це дозволить з'ясувати, сприйняття яких частот (високих чи низьких) більш порушене у цього хворого [5].

Слух вважається нормальним, якщо шепітна мова сприймається на відстані 6 м. Дослідження починають з близької відстані. Якщо хворий сприймає шепітну мову з цієї відстані, то лікар поступово відходить від пацієнта, поки останній почне неточно повторювати сказані слова. Ступенем сприйняття шепітної мови вважається найбільша відстань, з якої хворий правильно тричі повторює сказані лікарем слова.

Якщо при визначенні сприйняття шепітної мови виявлено порушення слуху, то визначають його гостроту за допомогою розмовної мови. Для цього вимовляють слова звичайною мовою. Починають визначення з близької відстані, поступово збільшуючи її доти, поки хворий перестане точно відтворювати почуте. Сприйняття розмовної мови в нормі складає 25 м. Але часто розміри кімнати, де проводять дослідження, недостатні для цього, в таких випадках рівнем сприйняття розмовної мови вважають «> 6 м». При значному зниженні слуху доводиться вимовляти слова біля самої вушної раковини або навіть говорити голосно, що і фіксується в документах як рівень дослідженого слуху - голосна мова. При дослідженні слуху розмовною мовою інше вухо, якщо його слухова функція збережена, медсестра повинна заглушити, наприклад, тріскачкою Барані [1].

\section{ДОСЛІДЖЕННЯ СЛУХУ КАМЕРТОНАМИ}

Проба Вебера. Озвучений камертон ставлять ніжкою в центрі чола чи тім'я хворого і просять вказати, яким вухом пацієнт чує звук гучніше, або у якому вусі відчувається звук (у правому чи у лівому). Якщо хворих вказує, що він краще чує звук одним вухом, то говорять про латералізацію звуку в праве чи у ліве вухо. Якщо хворий чує звук у центрі голови, то говорять про відсутність латералізації і називають «Вебер у голові». В нормі та за приблизно однакового зниження слуху на обидва вуха латералізації не має. При ураженні звукопровідного апарата (сірчана пробка в слуховому проході, запалення середнього вуха тощо) пацієнт буде довше і краще чути камертон хворим 
вухом. При ураженні звукосприймаючого апарата (сенсоневральна приглухуватість) звук камертона буде краще сприйматись здоровим вухом.

Дослід Федерічі - хворого просять закрити зовнішній слуховий прохід пальцем та почергово прикладають озвучений камертон до соскоподібного відростка та до козелка, визначаючи де раніше хворий перестане чути звук. У нормі та при ураженні звукопроведення звук камертона довше сприймається з козелка (дослід Федерічі позитивний). При ураженні звукопроведення звук із соскоподібного відростка сприймається довше, ніж з козелка (дослід Федерічі негативний).

Дослід Бінга - порівняння гучності сприйняття по тканинній провідності при закритому і відкритому зовнішньому слуховому проході. Ставлять озвучений камертон на соскоподібний відросток та періодично закривають і відкривають зовнішній слуховий прохід. У нормі та при ураженні звукосприймаючого апарата після закриття проходу звук відчувається краще (дослід Бінга позитивний). При ураженні звукопровідного апарата цього не виникає (дослід Бінга негативний) [4].

\section{АУДІОМЕТРІЯ}

Суб'єктивна аудіометрія - дослідження, результат якого залежить від відповідей обстежуваного. До цих методів належать тональна порогова (у тому числі дослідження в розширеному діапазоні частот) і надпорогова аудіометрія (дослідження функції гучності тест Люшера, SiSi-тест), мовна аудіометрія, визначення слухової чутливості до ультразвуків.

Надпорогова тональна аудіометрія - сукупність тестів дослідження слуху чистими тонами, інтенсивність яких перевищує мінімальний слух пацієнта. При цьому хворому пропонують прослухати та проаналізувати тони, що перевищують пороги слуху, визначені при пороговій тональній аудіометрії. Надпорогова аудіометрія дозволяє провести диференційну діагностику ураження завиткових рецепторів від інших порушень сенсоневральної системи [2].

Метою мовної аудіометрії $є$ визначення порогів розбірливості мови на різних інтенсивностях звуку.

\section{СПИСОК ЛІТЕРАТУРИ}

1. Затолока П. А. Методы исследования слуха : учеб.метод. пособ. / П. А. Затолока. - Минск : БГМУ, 2009. - 16 с.

2. Мітін Ю. В. Оториноларингологія (лекції) / Ю. В. Мітін. К. : Фарм Арт, 2000. - 304 с.

3. Пелымская Т. В. Методика педагогического обследования слуха детей с нарушенным слухом первого года жизни / Т. В. Пелымская, Н. Д. Шматко. - Альманах Института Коррекционной Педагогики РАО. - 2001. - № 3.
Імпедансна аудіометрія - об'єктивний спосіб визначення слухових порушень, а також зміни тиску в барабанній порожнині та наявності в ній рідини чи зрощень. Імпедансометрія ґрунтується на реєстрації звукових подразнень (стимулів), посланих до барабанної перетинки і відбитих від неї. Виявлено, що здатність барабанної перетинки поглинати чи відбивати звукову енергію залежить від ії імпедансу (опору), який, у свою чергу, пов'язаний з багатьма факторами (різниця тиску повітря в зовнішньому слуховому проході та у барабанній порожнині, зміни барабанної перетинки та барабанної порожнини тощо).

Об'єктивна аудіометрія - тобто такі дослідження, результати яких не залежать від відповідей паці$\epsilon$ нта. До таких методів належить імпедансометрія (реєстрація акустичного опору або імпедансу середнього вуха), реєстрація слухових викликаних потенціалів (комп'ютерна аудіометрія), електрокохлеографія (реєстрація потенціалів, які виникають у завитку при дії звуків), викликана отоакустична емісія [6].

На різниці в механізмі кісткової і повітряної провідності базуються методи диференційної діагностики уражень звукопровідного і звукосприймаючого апарата. При ураженні звукопровідного апарата краще сприймання звуків при проведенні їх через кістку, ніж через повітря.

Висновки. Своєчасне дослідження слуху за допомогою сучасних діагностичних методів та правильна оцінка потенційних можливостей слухової системи дітей дозволяє правильно оцінити їі стан. Суб'єктивні методи (дослідження слуху мовою, дослідження слуху за допомогою камертонів, суб'єктивна аудіометрія) та об'єктивні (об'єктивна (комп'ютерна) аудіометрія, акустична рефлексометрія, тимпанометрія, отоакустична емісія, безумовні рефлекторні реакції, умовні реакції на звук) дозволяють повною мірою оцінити стан слуху дитини та ступінь відхилень від норми. Адекватна і своєчасна діагностика розладів слуху в дітей сприяє їх подальшій успішній реабілітації, процесу навчання та соціальній адаптації дитини.

4. Шахова Е. Г. Новые подходы к лечению и профилактике сенсоневральной тугоухости / Е. Г. Шахова. M., 2008. - 210 c.

5. URL : http://intranet.tdmu.edu.ua/data/cd/ otolaryngologia/html/R3.htm

6. URL : https://studfiles.net/preview/2283091/page:6/

Отримано 04.04.18 